\title{
SATISFACTION, ENGAGEMENT AND ORGANISATIONAL COMMITMENT OF EMPLOYEES - REVIEW OF THE CONCEPTS AND PROPOSAL FOR A RESEARCH MODEL
}

\author{
Andrzej BOROWSKI \\ Maria Curie-Skłodowska University in Lublin, University College of Enterprise and Administration in Lublin; \\ a.borowski@wspa.pl
}

\begin{abstract}
Satisfaction, engagement and organisational commitment of employees are undoubtedly crucial elements when developing an effective organisation. The ambiguity of these concepts and the multiplicity of definitions hinder the analysis of the available studies. In this article, the author attempts to review the available concepts of these phenomena, indicates the relations between them as well as presents an original research model as a proposal for a starting point for further research.
\end{abstract}

Keywords: satisfaction, engagement, organisational commitment.

\section{Job satisfaction}

Although the origins of systematic job satisfaction surveys date back to the 1930s, this theme continues to intrigue the researchers and management practitioners. By observing the research of the last few years we can even talk about a Renaissance of the interest in this topic.

A review of the definitions indicates two ways of interpretation of the essence of job satisfaction and career contentment (Juchnowicz, 2014, p. 11):

1) The first way exposes the emotional nature of these concepts, limiting them to the sphere of feelings. E.A. Locke defines this concept as a "pleasurable emotional state that results from the perception that one's job fulfills or enables the fulfillment of one's important job values, providing and to the degree that those values are congruent with one's needs" (Locke, 1976) Cited Locke described job satisfaction as a result of the perception of one's own job as such that enables the achievement of important job values provided that those values are compatible with one's needs or help in the implementation of basic human needs. 
2) According to the second approach, job satisfaction and career contentment constitute a specific attitude towards work. The possibility to fulfill one's own values and objectives is seen as the basis for the development of employees' attitude towards their job. A representative of such an approach is V.H. Vroom, who defined satisfaction as an attitude; therefore, according to him, a positive attitude towards work is the same as job satisfaction. Vroom develops his considerations in the assumptions of the commonly known expectancy theory, where the key to employee satisfaction is to fulfill the employees' expectations (Vroom, 1964, p. 99).

It derives from the above definitions that what employees consider valuable at work results directly from their internal needs. At the same time, achieving results valued by employees is tantamount to their satisfaction.

Under the assumption that the job satisfaction is a part of the attitude, it seems necessary to cite its another definition. The most common definition of attitude is derived from social psychology where it is understood as a relatively permanent approach of an individual towards someone or something, an entity, object or idea. This approach involves three components: cognitive, affective and behavioural (Aronson, Wilson, and Akert, 2006, p. 81, 184-185). By applying the above definition to the workplace situation, the following components can be distinguished:

- in the cognitive aspect - the knowledge of employees on the performed work, awareness of the situation, judgements and opinions on the performed tasks and work environment,

- in the affective (emotional) aspect - affections and antipathies, both short-term and permanent attitude to the performed work, implemented tasks, objectives and people,

- in the behavioural aspect - tendencies and activities related to the subject towards which the attitude is analysed, which in this case is the performed work.

It should be noted that these components interact with each other and employees develop a number of partial attitudes (towards the job, co-workers or organisation) that ultimately determine the behaviour of the employee.

In some analyses of the behaviour of employees in the organisation, the attitude is identified both with the emotional (satisfaction) and normative aspect (a collection of opinions, judgements and beliefs) (Brief, and Weiss, 2002, p. 279-307). In many jobs, as well as management practices, the terms job satisfaction and career contentment are sometimes used interchangeably. It is difficult to presume that one can feel satisfaction and be discontent, and the other way around - be content and not satisfied. Therefore, the concept of job satisfaction and career contentment are treated in source literature, in dictionaries and in this article as synonyms (Słownik języka polskiego, 1989, p. 193, 900; Słownik synonimów, 2007, p. 380).

Diverse understanding of the concept of job satisfaction leads to problems when trying to compare the results of studies conducted on this subject. It seems indisputable that job 
satisfaction is a positive approach of employees to their duties, working environment and coworkers, and that this phenomenon is accompanied by a feeling of satisfaction.

Satisfaction can undoubtedly be a positive feeling, but it may also be negative. The same situation may be satisfying for one person and not for another. It consists of many elements and it is influenced by many factors of different value to different people.

The fact that engagement is strongly connected to satisfaction cannot be omitted. The existence of such a relationship is confirmed by D.A. Peterson (Peterson, 2004, p. 296319). According to M. Juchnowicz, job satisfaction and career contentment are the predictors of subsequent behaviour of employees in the form of their engagement (Juchnowicz, 2010, p. 59). Also according to M. Bugdol satisfaction may be a result of engagement. Without satisfaction there is no long-term engagement, and the short-term engagement may be forced (Bugdol, 2006, p. 89). Employee engagement may in turn result in civil behaviours. They are associated with taking voluntary actions by employees for the sake of the organisation; actions that are not explicitly included in the incentive systems.

\section{Engagement}

Employee engagement is important for the proper functioning of every organisation. From the point of view of an organisation, employee engagement may manifest itself in going beyond one's duties or showing initiative at work.

Table 1 provides an overview of the definitions of engagement occurring in the source literature.

Table 1.

An overview of the definitions of engagement

\begin{tabular}{|l|l|}
\hline \multicolumn{1}{|c|}{ Author } & \multicolumn{1}{c|}{ Definition } \\
\hline W.A. Kahn, 1990 & $\begin{array}{l}\text { It consists in expressing oneself in the working environment through goal-oriented } \\
\text { activities promoting relationship with the company, personal participation as well } \\
\text { as active and comprehensive fulfillment of roles. It is a psychological condition } \\
\text { that enables employees to express themselves physically, cognitively and } \\
\text { emotionally. }\end{array}$ \\
\hline W.A. Kahn, 1992 & $\begin{array}{l}\text { A dynamic, dialectical relationship between a person directing their personal } \\
\text { (physical, cognitive and emotional) energy towards fulfilling roles and a job that } \\
\text { makes it possible to express oneself. }\end{array}$ \\
\hline $\begin{array}{l}\text { M.P. Leiter, } \\
\text { C. Maslach }\end{array}$ & $\begin{array}{l}\text { The opposite of the negative state of burnout, understood as vivid experiencing of } \\
\text { the relationship with activities generating personal satisfaction and increasing the } \\
\text { sense of meaning of the professional efficiency of employees. }\end{array}$ \\
\hline $\begin{array}{l}\text { C. Maslach, } \\
\text { W.B. Schaufeli, } \\
\text { M.P. Leiter, 2001 }\end{array}$ & $\begin{array}{l}\text { Persistent, positive, emotional and motivational state of accomplishment } \\
\text { experienced by personnel, characterised by a high level of activity and pleasure. }\end{array}$ \\
\hline N.P. Rothbard, 2001 & $\begin{array}{l}\text { Two-dimensional motivational category including attention, relating to cognitive } \\
\text { abilities and time period devoted to think about a given task, and absorption, } \\
\text { meaning the level of absorption in the performed task and the intensity of attention } \\
\text { paid to that task. }\end{array}$ \\
\hline
\end{tabular}




\begin{tabular}{|c|c|}
\hline $\begin{array}{l}\text { W.N. Schaufeli, } \\
\text { M. Salanova, } \\
\text { V. González-Romá, } \\
\text { A.B. Bakker, } 2002\end{array}$ & $\begin{array}{l}\text { Positive, giving a sense of accomplishment, work-related state of mind } \\
\text { characterised by vigour, dedication to work and absorption in work. }\end{array}$ \\
\hline $\begin{array}{l}\text { J.K. Herter, } \\
\text { F.L. Schmid, } \\
\text { T.L. Hayes, } 2002\end{array}$ & It refers to passion and satisfaction with work, as well as the enthusiasm for work. \\
\hline $\begin{array}{l}\text { D.R. May, } \\
\text { R.L. Gilson, } \\
\text { L.M. Harter, } 2004\end{array}$ & $\begin{array}{l}\text { Employees express themselves in the physical, emotional and cognitive } \\
\text { aspect through engagement (conceptualisation of Kahn's definition, 1990). }\end{array}$ \\
\hline A.M. Saks, 2006 & $\begin{array}{l}\text { Separate and unique category that includes the cognitive, emotional and } \\
\text { behavioural components related to individual fulfillment of roles. }\end{array}$ \\
\hline M. Czarnowsky, 2008 & $\begin{array}{l}\text { Employees that are mentally and emotionally involved in their work and contribute } \\
\text { to the success of an organisation are referred to as engaged employees. }\end{array}$ \\
\hline $\begin{array}{l}\text { W.H. Macey, } \\
\text { B. Schneider, } 2008\end{array}$ & $\begin{array}{l}\text { Engagement understood as a feature refers to the character traits such as diligence, } \\
\text { initiative, positive impact; engagement as a condition includes feelings: energy, } \\
\text { absorption, satisfaction, participation, commitment and causative power; } \\
\text { engagement as a behaviour is understood as the fulfillment of the assigned roles } \\
\text { beyond the requirements, as civil behaviours, initiative and adaptive behaviours. }\end{array}$ \\
\hline $\begin{array}{l}\text { D.A. Newman, } \\
\text { D.A. Harrison, } 2008\end{array}$ & $\begin{array}{l}\text { Simultaneous presence of three elements in the behaviour of employees: efficient } \\
\text { work, civil behaviours and commitment. }\end{array}$ \\
\hline M. Juchnowicz, 2010 & $\begin{array}{l}\text { Attitude that makes it possible to treat engagement in a comprehensive manner } \\
\text { embracing elements of behaviour, emotions and interests (the relationship of } \\
\text { exchange between an employee and employer), formed under the influence of three } \\
\text { groups of factors: cognitive, emotional and behavioural. }\end{array}$ \\
\hline $\begin{array}{l}\text { M.S. Christian, } \\
\text { A.S. Garza, } \\
\text { J.E. Slaughter, } 2011\end{array}$ & $\begin{array}{l}\text { Relatively permanent state of mind relating to the simultaneous devotion of one's } \\
\text { personal energy to experiencing or performing work. }\end{array}$ \\
\hline
\end{tabular}

Source: Kmiotek, 2016, p. 63-64.

An interesting approach to the issue of work engagement is presented by W.B. Shaufeli et. al. Work engagement is defined by them as a positive, rewarding, work-related state of mind that reflects one's attitude towards the performed work (Schaufeli, Salanova, Gonz'alezRom'a, and Bakker, 2002, p. 71-92).

The division of engagement that occurs most frequently in source literature includes:

- work engagement,

- organisational engagement.

Work engagement is a term introduced by W.A. Kahn who defined it as physical, cognitive and emotional self-expression at work (Saks, 2006, p. 602). Therefore, personal engagement means undertaking tasks and putting energy into work-related behaviours. It is also a means for self-expression.

In contrast, organisational engagement is seen as an attitude that reflects the nature and quality of the relationship between an employee and an organization (Parish, Cadwallader, and Busch, 2008, p. 32-52), or as the extent to which an entity identifies itself with the objectives and values of an organisation in its work (Macey, and Schneider, 2008, p. 3-30). Organisational engagement can manifest itself in the following behaviours (Juchnowicz, 2010, p. 37): 
a) willingness to defend the company and its products in situations of crisis and conflict,

b) pride in one's work in the given organisation, identification expressed through statements such as "my company", "we", etc.,

c) demonstration of high activity and initiative,

d) long-term employment and lack of interest in changing the workplace,

e) availability and consent to work overtime when it is required by the situation,

f) understanding additional duties, willingness to take responsibility,

g) loyalty,

h) trust in superiors and co-workers.

In the English-language literature there are other similar concepts related to the involvement in professional activity, whose terms are difficult to distinguish in Polish, e.g. job involvement (Lodahl, and Kejner, p. 24-33), work involvement (Kanungo, 1982, p. 341349) or employee engagement (Schaufeli, and Bakker, 2010, p. 10-24). These terms are distinct from the term work engagement, conveying them in Polish may be problematic and the differences in meaning between them are significant.

$J o b$ involvement is a commitment to a particular professional activity carried out at a given time that satisfies the current needs of the subject. Work involvement means a commitment to work in general and is the result of perceiving work as a value in life. Employee engagement in turn, translated as "zaangażowanie pracownicze" (SzabowskaWalaszczyk, Zawadzka, and Wojtaś, 2011, p. 57-74), aims at prosperity and development of the company and not at the well-being (which is a consequence of engagement in work) of the employee.

When considering the issues associated with involvement, it cannot be ignored that the commitment to work, in particular in the form of being absorbed in work, determines the level of commitment to the organisation (the so-called "organisational commitment") (Meyer, and Allen, 1991, p. 61-89). Therefore, work engagement and organisational commitment are closely related to each other. It seems important to explore the determinants of the high level of both work engagement and organisational commitment.

For example, work engagement and organisational commitment of public and private sector employees were studied in Ghana using comparative approach. Findings showed a significant positive correlation between work engagement and organisational commitment. It was shown that employees of private organisations manifest a higher level of work engagement and organisational commitment than employees of public organisations (Agyemang, and Ofei, 2013, p. 20-23). 


\section{Organisational commitment}

As in the case of the term "engagement", there are numerous definitions of "organisational commitment" in the subject literature. Table 2 contains a list of the most common definitions of that concept.

Table 2.

Overview of the definitions of organisational commitment

\begin{tabular}{|c|c|}
\hline Author & Definition \\
\hline H.S. Becker, 1960 & $\begin{array}{l}\text { Tendency to engage in activities of a consistent sense of direction based on an } \\
\text { individual exploration of the costs related to terminating a relationship. }\end{array}$ \\
\hline R.M. Kanter, 1968 & $\begin{array}{l}\text { Readiness of social entities to devote their energy } \\
\text { and manifest loyalty to social systems. }\end{array}$ \\
\hline B. Buchanan, 1974 & $\begin{array}{l}\text { Awareness of lack of possibility to choose a different social identity or to reject a } \\
\text { specific requirement under a threat of penalty, or an emotional attachment to an } \\
\text { organisation with the exclusion of the purely instrumental value of a relationship. }\end{array}$ \\
\hline G.R. Salancik, 1977 & Condition in which a person feels obliged to act. \\
\hline $\begin{array}{l}\text { R.T. Mowday, } \\
\text { R.M. Steers, } \\
\text { L.M. Porter, } 1979\end{array}$ & $\begin{array}{l}\text { Relatively strong identification of a person with a particular organisation and } \\
\text { involvement in that organisation characterised by: } \\
\text { a) an acceptance and deep faith in the objectives and values of the organisation, } \\
\text { b) a willingness to put extra effort for the benefit of the organisation, } \\
\text { c) a strong need to maintain the membership. }\end{array}$ \\
\hline $\begin{array}{l}\text { E.A. Locke, K.N. Shaw, } \\
\text { L.M. Saari, G.P. Latham, } \\
1981\end{array}$ & $\begin{array}{l}\text { Determination in achieving objectives regardless of whether they are } \\
\text { commissioned, established in advance, or independently determined by the } \\
\text { participant. }\end{array}$ \\
\hline R.W. School, 1981 & $\begin{array}{l}\text { A stabilising force that maintains the course of action while the perspectives or } \\
\text { circumstances are unfavorable. }\end{array}$ \\
\hline Y. Wiener, 1982 & $\begin{array}{l}\text { Overall normative pressures to act in accordance with the course of action while } \\
\text { the perspectives or circumstances are unfavourable. }\end{array}$ \\
\hline A.E. Reichers, 1985 & $\begin{array}{l}\text { Process of identification with the objectives of many entities that constitute an } \\
\text { organisation (e.g. management, customers and trade unions). }\end{array}$ \\
\hline $\begin{array}{l}\text { C.A. O'Reily, } \\
\text { J. Chatman, } 1986\end{array}$ & $\begin{array}{l}\text { Psychological bond connecting a person with an organisation, reflecting the } \\
\text { degree of the person's internalisation or acceptance of an organisational } \\
\text { perspective. }\end{array}$ \\
\hline G. Blau, K. Boal, 1987 & $\begin{array}{l}\text { Condition in which an employee identifies oneself with a particular organisation } \\
\text { and its objectives, and wants to maintain the membership in order to support its } \\
\text { objectives. }\end{array}$ \\
\hline N. Oliver, 1990 & $\begin{array}{l}\text { Tendency of a person to act in a specific way targeted at the object (entity) of } \\
\text { attachment. }\end{array}$ \\
\hline $\begin{array}{l}\text { N.J. Allen, J.P. Meyer, } \\
1991\end{array}$ & $\begin{array}{l}\text { Psychological condition that binds a person to the organisation and makes leaving } \\
\text { the organisation less likely. }\end{array}$ \\
\hline $\begin{array}{l}\text { J.E. Mathieu, } \\
\text { D.M. Zajac, } 1990\end{array}$ & Bond or relation of a person with an organisation \\
\hline G.A. Zangaro, 2001 & $\begin{array}{l}\text { Act of oath or promise to someone or something to fulfill all obligations in the } \\
\text { future. A person who is involved in an organisation, is committed to it and } \\
\text { believes in its objectives and values. }\end{array}$ \\
\hline $\begin{array}{l}\text { J.P. Meyer, } \\
\text { L. Herscovitch, } 2001\end{array}$ & $\begin{array}{l}\text { A force that determines a person's course of action, resulting from the importance } \\
\text { of one or more entities for that person. Engagement described in such a way } \\
\text { differs from exchange-based motivational system and from goal-oriented } \\
\text { approach, and may influence behaviours in the situation of absence of extrinsic } \\
\text { motivational factors or positive attitude. }\end{array}$ \\
\hline
\end{tabular}

Source: Kmiotek, 2016, p. 22-23. 
One of the models of organisational commitment that are most often analysed by researchers is the three-component model of Meyer and Allen (Meyer, and Allen, 1991, p. 6189). This concept establishes that people commit to an organisation in three ways, so the proposed, operationalised model includes three types of commitment:

1) emotional (affective) commitment,

2) continuance commitment,

3) normative commitment.

Affective commitment is characterised by a high degree of commitment to an organisation and its objectives. An employee feels content and satisfied with being one of the members of a company, identifies with the organisation and its environment, manifests desire to work, as well as puts an effort in the implementation of tasks and missions of the company. The affective component then means an emotional attachment of an employee to the organisation, commitment to it and identification with it. Therefore, it can be concluded that employees strongly committed to the organisation in an affective manner are satisfied with work.

Continuance commitment is determined by the costs of leaving a company. This type of commitment develops when employees realise that they can lose what they have invested and achieved in the organisation if they leave, and when other work-related alternatives are limited. Therefore, the continuance commitment is an awareness of the costs related to leaving an organisation. With regard to the results of A. Bańka, it can be concluded that the longer the time of employment of an employee in a particular organisation, the higher the level of the employee's commitment, which manifests itself most through durability (Bańka, Bazińska, and Wołoska, 2002, p. 65-74). Therefore, it can be assumed that employees with longer working experience show greater commitment to the organisation, in particular in the case of continuance commitment.

Normative commitment refers to the feeling of obligation to stay in the organisation and continue the work; employees stay with a particular employer because they think that they should. It is formed on the basis of a mandatory duty and obligation which are based on: benefits and reciprocity principle, internalisation of social norms, or psychological contract. Organisational commitment understood in such a way indicates maintaining a relationship with the entity (organisation), and expresses a sense of moral obligation to remain in the organisation.

Studies show that organisational commitment leads to significant results such as: turnover increase, better motivation, growth of civil behaviours in organisations, organisational support (Kwon, and Banks, 2004, p. 602-622). Employees who are strongly committed to the organisation in an affective manner work more and get better results than those who present a low level of emotional commitment. Similar but poorer results are observed in the case of normative commitment. However, the correlation between continuance commitment and work results is unclear. Some studies suggest that there is no statistically significant correlation 
between these variables. However, there are indications that employees with a higher level of continuance commitment show lower efficiency and poorer results (Spik, and Klincewicz, 2008, p. 489). A high level of affective and normative commitment is beneficial from the point of view of organisations, although the beneficial effects of the normative commitment are weaker and may be short-lived.

Therefore, from the point of view of organisation it is beneficial when its employees are experiencing the affective commitment. Emotional commitment is beneficial both for the employee and for the organisation; it evokes both positive emotions and attitudes towards the organisation and satisfaction with opportunities as well as enables self-realisation through work.

\section{Relations between satisfaction and engagement}

Analysis of the literature and empirical studies prove the correlation between satisfaction and engagement of employees and their commitment to the organization (Juchnowicz, 2009, p. 121-127). The subject of this discussion is the direction of these correlations and the answer to the question whether satisfaction influences engagement or the other way around engagement determines job satisfaction. Management sciences and social psychology are dominated by the assumption that job satisfaction has positive impact on the level of engagement (Schultz, and Schultz, 2002, p. 307).

It is difficult to prove the explicit impact due to the fact that higher and better results may not occur, often for objective reasons, immediately after the occurrence of the conditions that have positive impact on the level of job satisfaction. Furthermore, the direction and force of the impact are determined by many external and personal factors. The notion of the coexistence of these two attitudes towards work was formed on the basis of the above and not on the basis of a cause and effect relationship (Bowling, 2007, p. 167-185).

Numerous models have been devoted to the relations between satisfaction and engagement and to the factors that shape them. One of the most popular models is the one proposed by W.B. Schaufeli and A.B. Bakker (Schaufeli, and Bakker, 2006, p. 41-50). Scientists admitted that it is impossible to formulate a comprehensive definition of engagement that would include all of the proposed approaches towards it, so they made an attempt to integrate the academic experience and proposed a model of engagement functioning in literature as a demands-resources model (fig. 1). In their model, the authors define work engagement as a specific psychological condition (which involves spending one's personal energy) consisting of vigour, dedication to work and preoccupation with it. They concluded that engagement is a factor that mediates the relationship between the influence of job resources and the influence of personal resources on organisational results. Work-related 
circumstances (e.g. a job that is demanding and makes it possible to prove oneself) have a motivational potential that results in high engagement rate and excellent results. That motivational potential refers not only to intrinsic motivation (employee development, learning) but also to extrinsic motivation (means of achieving the objectives pursued). According to the authors, to evoke a specific psychological conditions some personal predispositions (e.g. optimism, self-esteem, faith in one's efficiency), which also have a motivational potential, are also necessary. At the same time, they show that job satisfaction along with commitment to work (the categories partly overlapping with work engagement) play a similar, intermediary role in the obtained results. Due to the fact that this is just a partial overlap, the authors deem it necessary to indicate those three positive psychological conditions as intermediary categories.

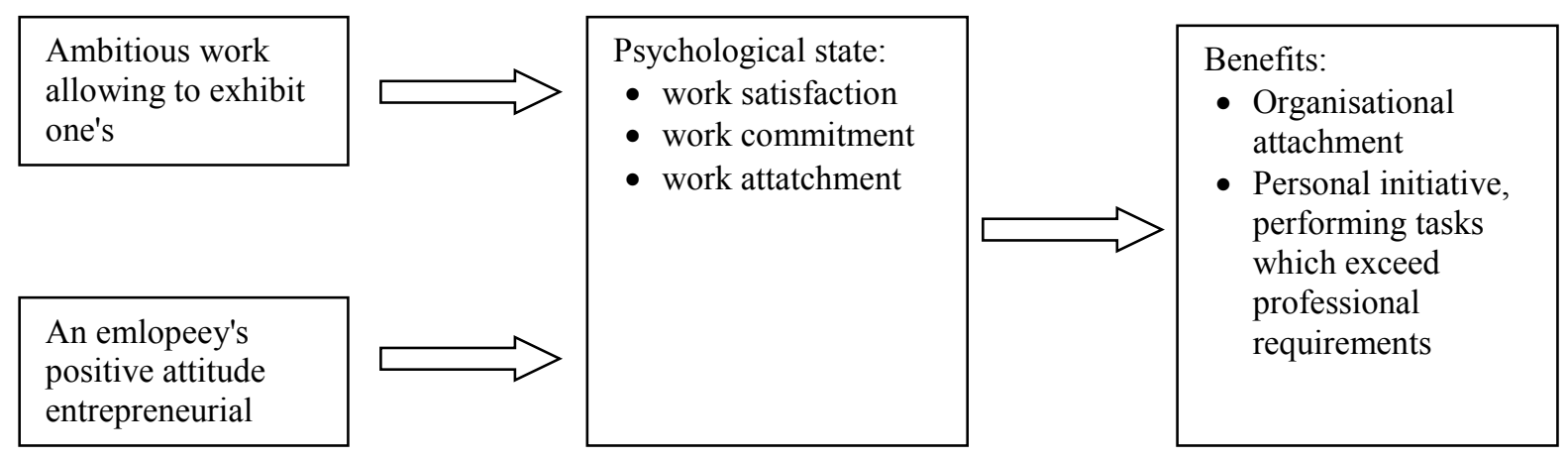

Figure 1. Model of engagement by W.B. Shaufeli and A.B. Bakker. Adapted from "Defining and measuring engagement in a cross-cultural workforce: new insights for global companies" by W.B. Schaufeli, A.B. Bakker. Global Business and Organizational Excellence, Vol. 26, Iss. 1, p. 41. Copyright 2006.

The question concerning the factors that influence satisfaction to the largest extent remains open. M. Juchnowicz believes that they include communication, organisation of work, relations with superiors, career development, human relations and remuneration (Juchnowicz, 2014, p. 65), and these factors have been implemented to the model proposed by the author of the article (fig. 2). According to the proposed model, these factors affect satisfaction and this in turn determines work engagement and organisational commitment. 


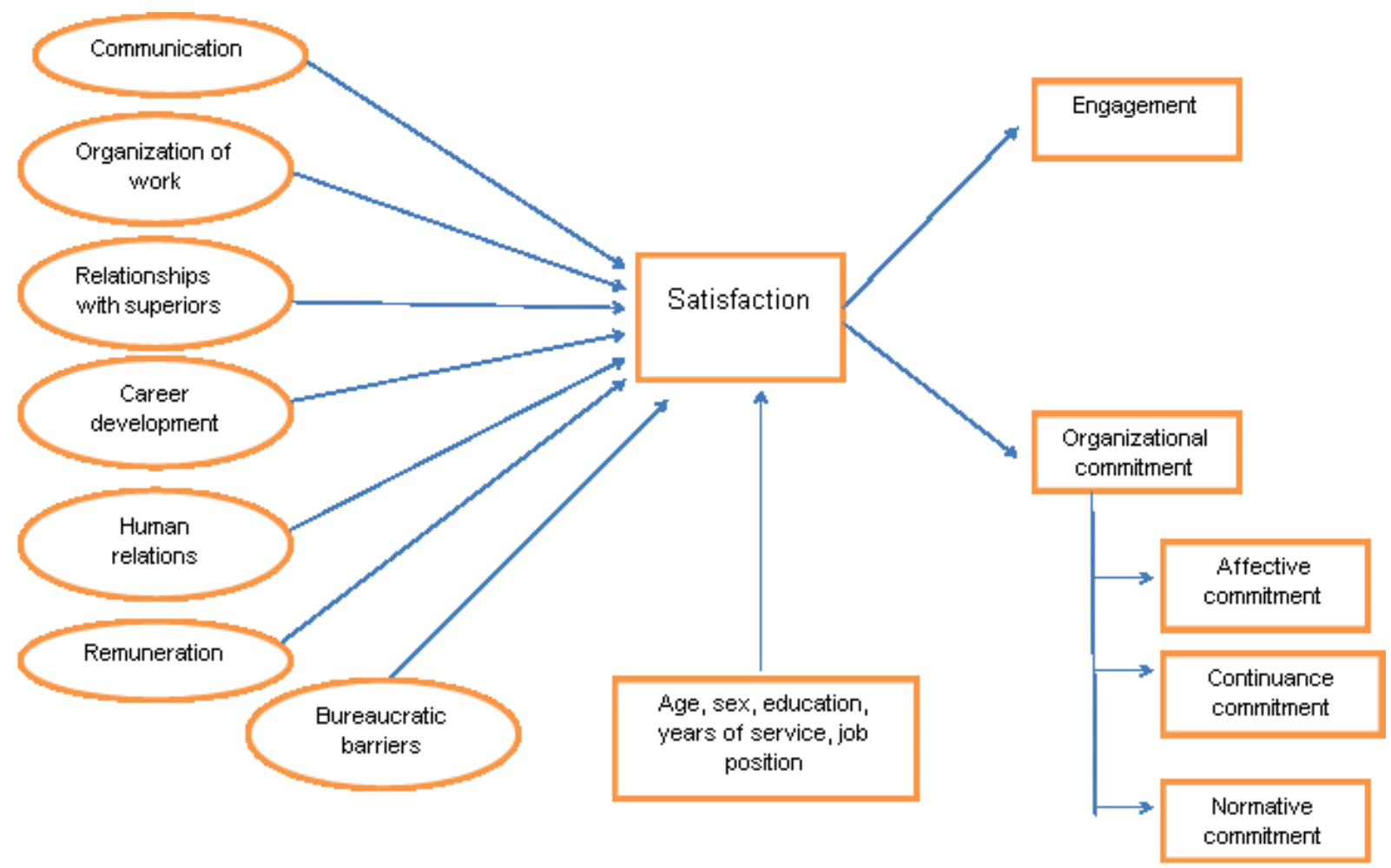

Figure 2. Satisfaction in the employee management model (research model). Own study.

\section{Pilot study}

The research tool used to verify the presented model (fig. 2) was a survey questionnaire consisting of fifty-five questions, the vast majority of which was verified in other studies. Nineteen questions concerned human resources (Juchnowicz, 2014, p. 166) management practices, two concerned bureaucratic barriers, five concerned job satisfaction (Zalewska, 2003 b, p. 54), nine questions were taken from the UWES-9 test (Seppälä, Mauno, Eldt, Hakanen, Kinnunen, Tolvanen, and Schaufeli, 2008, p. 479), eighteen questions regarding organisational commitment were taken from A. Bańka's version of Meyer and Allen's test (Bańka, Bazińska, and Wołoska, 2002, p. 70) two questions about resources were also added.

\subsection{Research method}

A pilot study was conducted between December 2015 and February 2016 using a survey questionnaire. A link to the survey was sent to capital cities of 16 provinces and to 60 municipal offices throughout the country. As a result of the conducted survey, 88 completed survey questionnaires were received, which have been subject to a statistical analysis described below.

At the beginning it was examined whether the theoretically extracted factors shaping satisfaction will also be determined analytically. For this purpose, a factor analysis was 
carried out for 6 factors using principal component analysis with two rotation methods Varimax rotation and direct Oblimin rotation. Varimax rotation is based on choosing such factors so that the inter-factor variation was as high as possible and the intra-factor variation as low as possible. Direct Oblimin rotation is based on the correlation between the variables which form each factor. The Varimax rotation was conducted first. The results of the KMO and Bartlett's Test are presented in Table 3.

\section{Table 3.}

Kaiser-Mayer-Olkin and Bartlett's Test

\begin{tabular}{|l|c|}
\hline The KMO measure of sampling adequacy. & 0.847 \\
Bartlett's Test of Sphericity Chi-squared approximation & 845.590 \\
Df & 153 \\
Significance & 0.000 \\
\hline
\end{tabular}

Source: Own study based on the pilot study results.

The KMO test verified if reduction of the dimensions would produce results, i.e. if it makes sense to switch the 18 questions to a smaller number of indicators. A measure of above 0.5 indicates the merits of the application of factor analysis. It can be said that it was deducted, on the basis of the $\mathrm{KMO}=0.85$ result, that the reduction of the dimensions would bring significant results.

Then the Bartlett's test was checked. Based on the $\mathrm{x} 2(153)=845.59 ; \mathrm{p}<0.001$ results of Bartlett's Test of Sphericity it was found that there were significant correlations between the parameters, therefore it was necessary to conduct a factor analysis in order to extract the factors. An indication as to the number of factors was Cattell's criterion based on a scree plot (fig. 3).

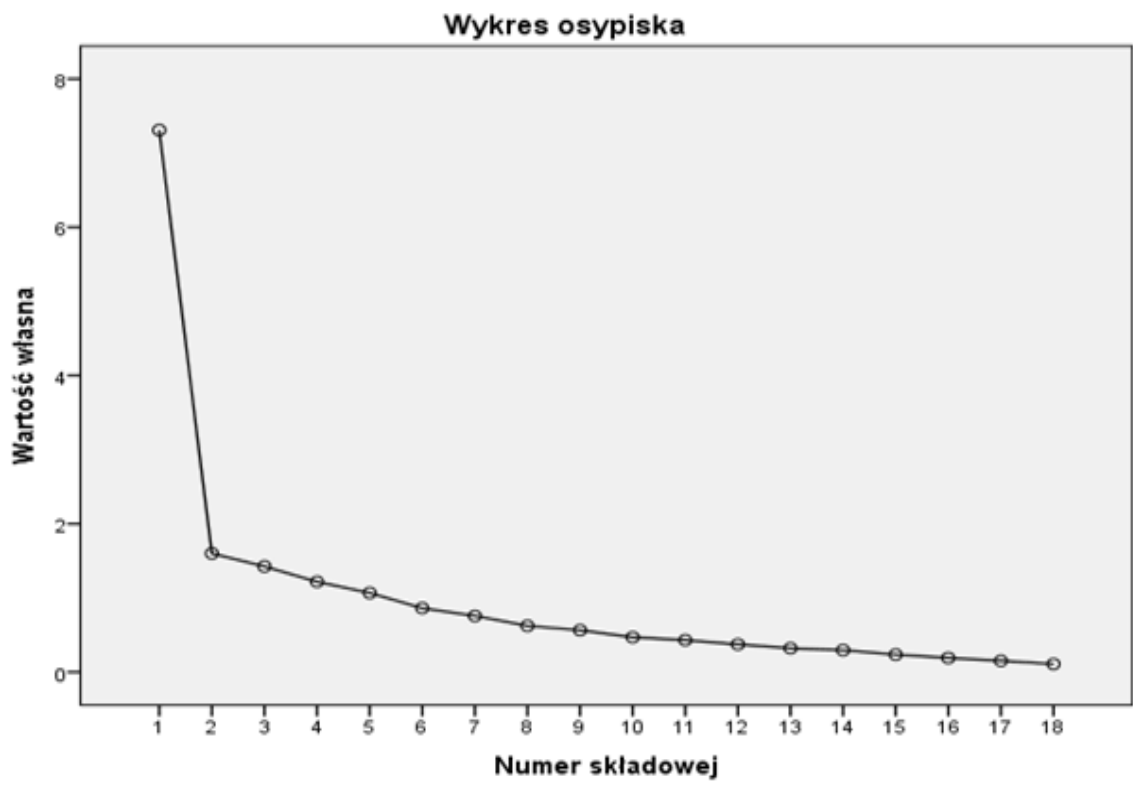

Figure 3. Scree plot. Source: Own study on the basis of pilot study. 
The eigenvalue by which the curve starts to level off indicates the number of factors that should be extracted. It can be said that it was stated on the basis of Cattell's criterion that builds on the scree plot that it is worth to consider the extraction of two factors.

After conducting the factor analysis, the reliability of Cronbach's Alpha was analysed. The reliability of the scale is understood as the accuracy of the measurement. The Cronbach's Alpha measure determines the coherence of the values included in a given scale, in other words it determines whether the way of answering the questions was coherent. The higher the Cronbach's Alpha coefficient the more coherent the ratio that the measurements compose. It is assumed that values within the limits of 0.6-0.7 mean a satisfactory level of scale reliability in scientific research.

\section{Table 4.}

Reliability of the factors that shape satisfaction

\begin{tabular}{|l|c|}
\hline Factors & Cronbach's Alpha coefficient \\
\hline Career development & 0.606 \\
\hline Remuneration & 0.651 \\
\hline Relations with superior & 0.883 \\
\hline Human relations & 0.880 \\
\hline Communication & 0.672 \\
\hline Organisation of work & 0.700 \\
\hline
\end{tabular}

Source: Own study based on the pilot study results.

It is visible above that even though the factor analysis did not show 6 factors, the reliability analysis for career development, communication and remuneration was only slightly below 0.7 , and for other factors it was above this value. Therefore, it can be stated that the factors showed high reliability and the questions they included were coherent.

\section{Summary}

As presented in the article, there is no single, consistent definition of satisfaction, engagement and organisational commitment. The debate on these terms is still valid and attracts the interest of researchers. Similarly, the force and direction of the relations between these phenomena are ambiguous. Therefore, it is necessary to conduct further research on them and, as it has been shown, the model proposed by the author seems to be a good concept and a starting point for further works. 


\section{Bibliography}

1. Agyemang, C.B., and Ofei, S.B. (2013). Employee Work Engagement and Organizational Commitment: A Comparative Study of Private and Public Sector Organizations in Ghana. European Journal of Business and Innovation Research Vol. 1, No. 4, p. 20-33.

2. Aronson, E., Wilson, T.D., and Akert, R.M. (2006). Psychologia społeczna (p. 81, 184185), Poznań.

3. Bańka, A. (2002). Psychologia organizacji. In J. Strelau (ed.), Psychologia podręcznik akademicki. Gdańsk: GWP.

4. Bańka, A., Bazińska, R., and Wołoska, A. (2002). Polska Wersja Meyera i Alen Skali Przywiązania do Organizacji. Czasopismo Psychologiczne, Vol. 8(0), p. 65-74.

5. Bowling, N. (2007). Is the job satisfaction-job performance relationship supurius? A meta-analitic examination. Journal of Vocational Behavior, No. 2.

6. Brief, A.P., and Weiss, H.M. (2002). Organizational behavior: Affect in the workplace. Annual Review of Psychology, Vol. 53, p. 279-307.

7. Bugdol, M. (2006). Wartości organizacyjne. Szkice z teorii i zarządzania. Kraków: Wydawnictwo Uniwersytetu Jagiellońskiego.

8. Juchnowicz, M. (2004). Kapitał ludzki a ksztattowanie przedsiębiorczości. Warszawa: Poltext.

9. Juchnowicz, M. (2009). Postawy Polaków wobec pracy w zarządzaniu kapitatem ludzkim. Kraków: Oficyna Wolters Kluwer business.

10. Juchnowicz, M. (2014). Satysfakcja zawodowa pracowników. Kreator kapitału ludzkiego. Warszawa: PWE.

11. Juchnowicz, M. (red.) (2010). Zarządzanie przez zaangażowanie. Warszawa: PWE.

12. Kanungo, R.N. (1982). Measurement of job and work involvement. Journal of Applied Psychology, Vol. 67(3), p. 341-349. Retrieved from http://dx.doi.org/10.1037/00219010.67.3.341.

13. Kmiotek, K. (2016). Zaangażowanie pracowników w miejscu pracy. Rzeszów: Oficyna Wydawnicza Politechniki Rzeszowskiej.

14. Kwon, I.G., and Banks, D.W. (2004). Factors related to the organizational and professional commitment of internal auditors. Managerial Auditing Journal, Vol. 16, No. 5 .

15. Locke, E.A. (1976). The nature of causes of job satisfaction. M.D. Dunette Handbook of industrial and organizational psychology. Chicago: Rand Mcnally.

16. Lodahl, T.M., Kejner, M. (1965). The definition and measurement of job involvement. Journal of Applied Psychology, Vol. 49(1), p. 24-33. Retrieved from http://dx.doi.org/ 10.1037/h0021692. 
17. Macey, W.H., Schneider, B. (2008). The meaning of employee engagement. Industrial and Organizational Psychology, Vol. 1, No. 1.

18. Meyer, J.P., and Allen, N.J. (1991). A three-component conceptualization of organizational commitment. Human Resource Management Review, Vol. 1(61).

19. Meyer, J.P., and Allen, N.J. (1997). Commitment in the Workplace: Theory, Research, and Application. Thousand Oaks: SAGE Publications.

20. Parish, J.T., Cadwallader, S., and Busch, P. (2008). Want to, need to, ought to: employee commitment to organizational change. Journal of Organizational Change Management, Vol. 21, No. 1 .

21. Peterson, D.K. (2004). The Relationship Between Perceptions of Corporate Citizenship and Organizational Commitment. Business \& Society, Vol. 43, No. 3.

22. Peterson, U., Demerouti, E., Bergström, G., Samuelsson, M., Asberg, M., and Nygren, A. (2008). Burnout and physical and mental health among Swedish healthcare workers. J. Adv. Nurs. Vol. 62(1), p. 84-95. Retrieved from http://dx.doi.org/10.1111/j.13652648.2007.04580.x.

23. Saks, A. (2006). Antecedents and consequences of employee engagement. Toronto, Canada: Joseph L. Rotman School of Management, Centre for Industrial relations and Human Resources, University of Toronto.

24. Schaufeli, W.B., and Bakker, A.B. (2006). Defining and measuring engagement in a cross-cultural workforce: new insights for global companies. Global Business and Organizational Excellence, Vol. 26, Iss. 1.

25. Schaufeli, W.B., and Bakker, A.B. (2010). The conceptualization and measurement of work engagement: A review. In A.B. Bakker, and M.P. Leiter (eds.). Work engagement: $A$ handbook of essential theory and research (p. 10-24). New York: Psychology Press.

26. Schultz, D.P., and Schultz, S.E. (2002). Psychologia a wyzwania dzisiejszej pracy. Warszawa: PWN.

27. Seppälä, P., Mauno, S., Eldt, T., Hakanen, J., Kinnunen, U., Tolvanen, A., and Schaufeli, W. (2008). The Construct Validity of the Utrecht Work Engagement Scale: Mulisample and Longitudinal Evidence. Springer Science+Business Media B.V.

28. Słownik języka polskiego PWN. PWN. Retrieved from www.sjp.pwn.pl.

29. Słownik języka polskiego, t. III (1989). Warszawa: PWN.

30. Spik, A., and Klincewicz, K. (2008). Nowe kierunki w zarządzaniu ludźmi zaangażowanie organizacyjne. Warszawa: Wydawnictwo Akademickie i Profesjonalne.

31. Szabowska-Walaszczyk, A., Zawadzka, A.M., and Wojtaś, M. (2011). Zaangażowanie w prace i jego korelaty: Adaptacja skali UWES autorstwa Schaufeliego i Bakkera. Psychologia Jakości Życia, nr 10.

32. Vroom, V.H. (1964). Work and Motivation. New York: Wiley \& Sons. 
33. Zalewska, A. (2003a). Dwa światy. Emocjonalne i poznawcze oceny jakości życia i ich uwarunkowania u osób o wysokiej i niskiej reaktywności. Warszawa: Wydawnictwo SWPS Academica.

34. Zalewska, A. (2003b). Skala satysfakcji z pracy - pomiar poznawczy aspektu ogólnego zadowolenia z pracy. Acta Universitatis Lodziensis. Folia Psychologica, Vol. 7.

35. Zalewska, A. (2004). Transactional model of subjective well-being. Polish Psychological Bulletin, Vol. 35(1).

36. Zalewska, A. (2006). Związki pomiędzy potrzebą aprobaty społecznej a zadowoleniem z pracy w badaniach anonimowych. Roczniki Psychologiczne, $n r$ 9(2).

37. Zalewska, A. (2007). Rodzaj wykonywane wykonywanego zawodu i reaktywność a zadowolenie z pracy. Psychologia-Etologia-Genetyka, $n r$ 15, p. 87-110. 